\title{
Oroantral communication closure using a pedicled buccal fat pad graft
}

\section{Fechamento de comunicação buco-sinusal utilizando enxerto pediculado de corpo adiposo da bochecha}

\begin{abstract}
Purpose: This paper reports the procedure used to close a late oroantral fistula using rotating flaps of the pedicled buccal fat pad.

Case description: A 66-year-old, male patient with leukoderma, in good general health, was referred for closure of an extensive late oroantral communication. Upon clinical examination, an approximately $10-\mathrm{mm}$ fistula was observed connecting the oral cavity to the maxillary sinus. An outpatient surgical procedure was performed with the use of local anesthetics to close the oroantral fistula with a rotating pedicled buccal fat pad flap. The healing of the wound and closure of the defect could be seen after a 30-day postoperative period, with complete epithelialization.

Conclusion: Grafting of the pedicled buccal fat pad is thought to be an efficient, safe and easy alternative to a larger oroantral fistula closure. Pedicled buccal fat pad grafting corrected the defect without generating any sequelae and/or great postoperative discomfort to the patient.
\end{abstract}

Key words: Oral fistula; oroantral fistula

\section{Resumo}

Objetivo: $O$ objetivo desde artigo foi relatar um caso clínico de fechamento de fístula bucosinusal tardia utilizando rotação de enxerto de tecido adiposo pediculado do corpo adiposo da bochecha.

Descrição do caso: Paciente do sexo masculino, 66 anos, leucoderma, em boas condições de saúde geral, foi encaminhado para fechamento de extensa comunicação buco-sinusal. Ao exame clínico, observou-se uma fístula de aproximadamente $10 \mathrm{~mm}$ de diâmetro comunicando a cavidade oral com o seio maxilar. A cirurgia foi realizada em nível ambulatorial, sob anestesia local, para fechar a fístula buco-sinusal com um enxerto de tecido adiposo pediculado do corpo adiposo da bochecha. A reparação da ferida e o fechamento do defeito foram observados no pós-operatório de 30 dias, com completa epitelização.

Conclusão: $O$ enxerto pediculado de tecido do corpo adiposo da bochecha mostrou-se uma alternativa simples, eficaz e segura no fechamento mediato da fístula buco-sinusal apresentada neste caso clínico.

Palavras-chave: Fístula bucal; fístula buco-antral

\author{
Ruy de Oliveira Veras Filho a \\ Fernando Giovanellab \\ Rafael Machado Karsburg ${ }^{c}$ \\ Marcos Antonio Torrianid
}

\begin{abstract}
- Residency Program in Oral and Maxillofacial Trauma and Surgery, Araraquara School of Dentistry, UNESP, Araraquara, SP, Brazil

b Specialty Training Course in Oral and Maxillofacial Surgery, UFPel, Pelotas, RS, Brazil

Tutorial Educational Program of the Course of Dentistry, UFPel, Pelotas, RS, Brazil

${ }^{d}$ Department of Oral and Maxillofacial Surgery and Trauma, UFPel, Pelotas, RS, Brazil
\end{abstract}

Correspondence:

Marcos Antonio Torriani

Rua Gonçalves Chaves, 457, $3^{\circ}$ andar

Pelotas, RS - Brasil

E-mail: marcostorriani@gmail.com 


\section{Introduction}

Oroantral communications (OAC) are common surgical complications of dental procedures $(1,2)$. An oroantral fistula is a pathological condition in which the oral and antral cavities have a permanent communication by means of a fibrous conjunctive tissue fistula coated by epithelium (3). OACs $2 \mathrm{~mm}$ in diameter or smaller are likely to close spontaneously, without the need for surgical intervention. However, OACs $3 \mathrm{~mm}$ in diameter or larger, or OACs associated with maxillary or periodontal inflammation, may persist (4), and surgical closure is recommended. Several techniques have been used for OAC resolution, such as the use of mucoperiosteal flaps (vestibular, palatine, lingual or combined), bone grafts (5), or buccal fat pad grafts (Bichat ball) $(6,7)$.

The buccal fat pad is made up of a central adipose mass with four extensions (buccal, pterygoid, superficial and deep temporal), with a $10-\mathrm{mL}$ volume and a thickness of 6 $\mathrm{mm}(8)$. The buccal fat pad is surrounded by a thin fibrous capsule (5). Blood supply is provided by the vestibular and deep branches of the maxillary artery, the transverse facial branches of the superficial temporal artery and branches of the facial artery $(6,8)$.

The buccal fat pad structure can be used in the correction of several oral defects, such as fistulas and oroantral communications $(5,7)$; in reconstruction after tumor resection (6); in rehabilitation of cleft patients (9); in aesthetic corrections of the face; and in implant-graft coating (10). The scope of defects that can be treated using the pedicled buccal fat pad flap varies according to the patient's morphology, as this structure varies in dimension from one individual to another. Oral defect closure using the buccal fat pad has been increasingly employed because it is a fast surgical procedure, is relatively easy to perform, has a high success rate (11), and is able to cover defects of up to $60 \times 50 \mathrm{~mm}(12,13)$.

The aim of this paper was to report a clinical case of late closure of an oroantral fistula using a rotating pedicled buccal fat pad flap.

\section{Description of the case}

A 66-year-old male patient with leukoderma, in good general health, presented with an extensive oroantral communication in the right premolar and molar area in the maxilla. There were no clinical signs of a sinus condition. The patient's chief complaint was liquid outflow through his nose and food inflow through the communication after tooth extraction in the area. Clinical examination revealed an approximately $10-\mathrm{mm}$ fistula linking the oral cavity to the maxillary sinus, with no pus or systemic inflammatory signs (Fig. 1A). A Water's radiographic image confirmed the clinical findings of an oral fistula with no maxillary sinus condition.

The patient was instructed to irrigate the maxillary sinus with a $9 \%$ saline solution daily over a three-day period before surgery. A surgical outpatient procedure was performed with local anesthetic consisting of 2\% mepivacaine and 1:100,000 adrenaline.

The surgical procedure (Fig. 1B) consisted of a circular incision on the fistula's border to free the mucosa from the bone tissue to allow the closing of the borders by means of an absorbable 4-0 catgut suture, internally sealing the communication (Fig. 1C). A linear incision on the border was divulsed to allow the incision of the periosteum and to give access to the buccal fat pad. The buccal fat pad was dragged into the fistula site so that the latter was completely covered (Fig. 1D), then sutured with simple 4-0 silk thread stitches, without tension (Fig. 1E).

The suture was removed after a 15-day postoperative period without complications; the patient presented an advanced proliferation of epithelial tissue of the mucosa on the fat tissue. Thirty days after surgery, the healing of the wound and the complete closure of the defect, which was completely epithelialized, could be noted (Fig. 1F).

\section{Discussion}

Detailed clinical and radiographic exams in the postoperative period are of utmost importance in surgical planning of cases in which there is a possibility of oroantral communication occurrence; these data allow the surgeon to perform the procedure with greater care and planning, should communication occur as a postoperative complication.

OACs have various etiologies, one of the most frequent of which is exodonty of the maxillary posterior teeth - the cause of the communication described in this clinical case. OACs must be treated as soon as possible to avoid sinus conditions, which can prevent the treatment of the lesion and the resolution of the case. Treatment of OACs identified in their early stages is based on a surgical procedure that provides adequate communication closure and the correct patient instructions to avoiding changes in pressure in the upper airways during the recovery period (14). In cases when OAC is identified later, the initial procedure should be the analysis of the maxillary sinus to determine if there is a sinus condition associated with the communication. In this case, the infection must be resolved before any surgical procedure for OAC closure is undertaken, and sinus irrigation plus systemic antibiotic therapy should be used.

The buccal flap technique can be satisfactorily employed in the treatment of small and medium-sized communications, but its use is restricted to conditions when the defect has been dislocated to the palatine area due to a greater buccal loss, which requires a greater flap sliding. The rotation of the palatal flap can be used to solve important communications without harming the vestibular sulcus, although this procedure creates great morbidity due to the open area it creates in the palate. This open area demands a long postoperative care period, generating great discomfort to the patient. 

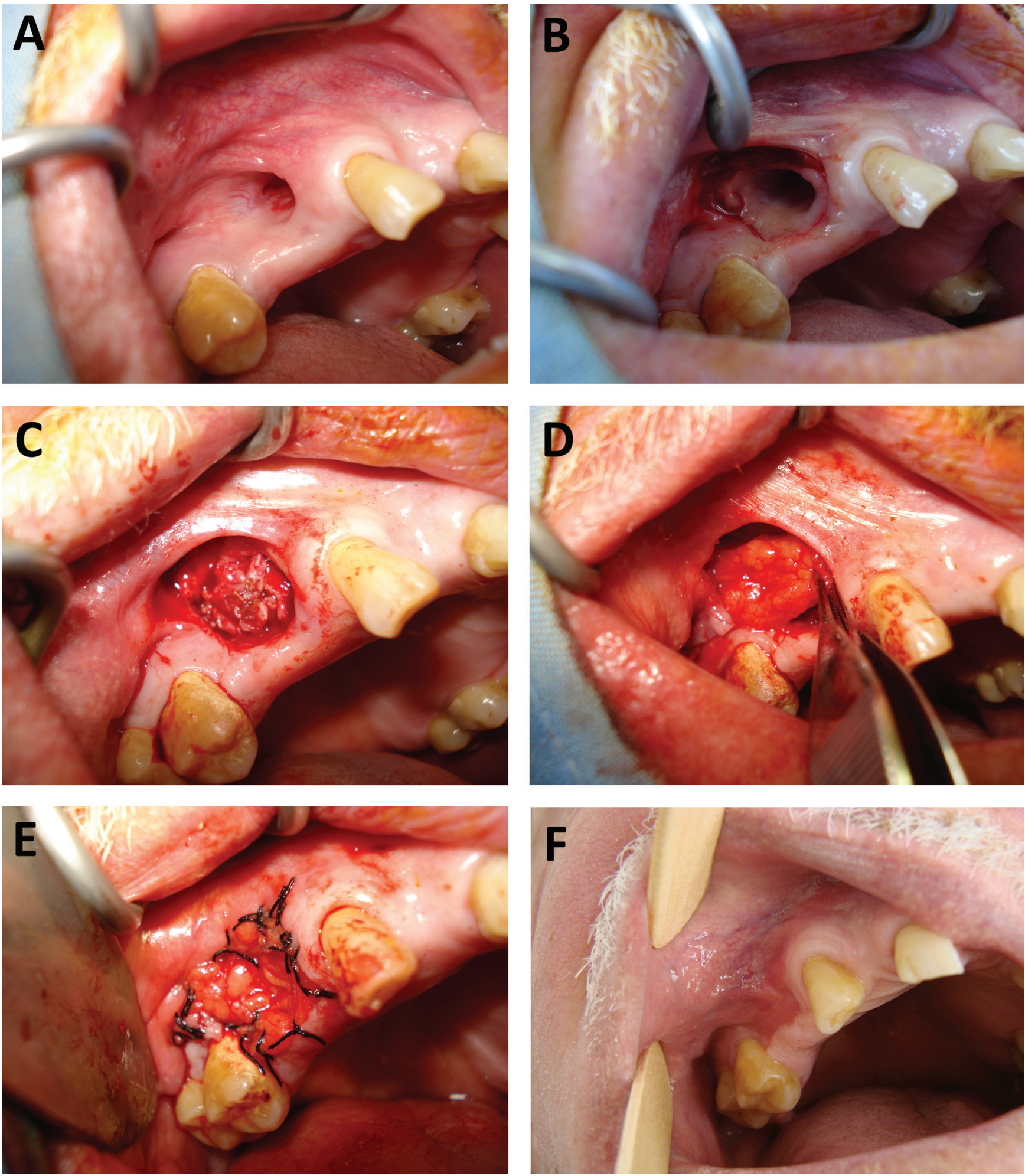

Fig. 1. Case of oroantral communication closure using a pedicled buccal fat pad graft. (A) Late bucco-sinusal fistula in the 15-16 tooth area. (B) Circular incision around the fistula and mucosa displacement on the fistulous path. (C) Absorbable 4-0 catgut suture on the right maxillary sinus mucosa. (D) Buccal fat pad dragging into the fistula site. (E) 4-0 silk suture in isolated places around the fat tissue. (F) Tissue repair in the 30-day postoperative follow-up. 
Pedicled buccal fat pad flaps have been recommended for the closure of fistulas and communications of varied sizes and locations; the use of pedicled buccal fat pad flaps has also been employed in the resolution of unsuccessful surgical cases in which lesions have developed. Among the advantages of this technique are the low morbidity rate, maintenance of the vestibular sulcus depth, its high applicability, the low incidence of failure, and the good flap vascularization and size $(7,15)$. According to Hanazana $(7)$, when fat tissue is exposed to the oral environment, it becomes epithelialized and is gradually replaced by fibrous conjunctive tissue within a 30-40-day postoperative period, without any functional damage to the treated site.

The use of the pedicled buccal fat pad flap technique in the resolution of the case described here was due to the lesion location on the vestibular sulcus of the right maxillary alveolar bone, which prevented the palatal rotating flap technique from being used, as this would demand a very large flap to cover the fistula. The location also explains the non-use of the buccal flap sliding technique, which would cause vestibular sulcus depth loss.

A factor considered in choosing the postoperative technique was the large communication size, which made the other previously mentioned techniques less suitable and favored the use of the buccal fat pad as a pedicled graft source for the lesion resolution. The surgery was performed without intercurrences, and the lesion was coated by the graft with no difficulties. Discomfort during the recovery period was not reported by the patient, who was referred to dental prosthetic rehabilitation 30 days after surgery.

In the case reported, the pedicled buccal fat pad graft proved to be an easy, efficient and safe alternative for the immediate closure of the oroantral fistula, allowing the resolution of the defect without generating sequelae or excessive postoperative discomfort to the patient. The exposed fat tissue underwent a coating process by the normal surrounding mucosa in a short time in the postoperative period, resulting in the total regeneration of the treated area.

\section{References}

1. Ericson S, Finne K, Persson G. A clinical-radiographic review of treated oro-antral communications. Int J Oral Surg 1973;2:185.

2. Killey HC, Kay LW. An analysis of 250 cases of oro-antral fistula treated by the buccal flap operation. Oral Surg Oral Med Oral Path 1967;24:726-39.

3. Gregori C. Cirurgia Buco-Dento-Alveolar. $2^{a}$ ed. São Paulo: Sarvier; 1996.

4. Schuchardt K: Treatment of oro-antral perforations and fistulae. Int Dent J 1955; 5:159.

5. Pereira FL, Farah GJ, Passeri LG, Pavan AJ. Aplicação do corpo adiposo bucal para o encerramento de fístula bucosinusal. Relato de caso. Rev Port Estomatol Cir Maxilofac 2004;45:221-6.

6. Tideman H, Bosanquet A, Scott J. Use of the buccal fat pad as a pedicled graft. J Oral Maxillofac Surg 1986;44:435-40.

7. Hanazawa Y, Itoh K, Mabashi T, Sato K.. Closure of oroantral communications using a pedicled buccal fat pad graft. J Oral Maxillofac Surg 1995;53:771-5.

8. Dubin B, Jackson IT, Halim A, Triplett WW, Ferreira M, Stuzin J, Baker T. Anatomy of the buccal fat pad and its clinical significance. Plast Reconstr Surg 1989;83:257-64.
9. Garcia RR, Rabêlo LRS, Moraes M, Moreira RWF, AlbergariaBarbosa JR. Utilização de enxerto pediculado do corpo adiposo da bochecha no tratamento de comunicações oro-antrais. Rev Port Estomatol Cir Maxilofac 2000;4 1:17-24.

10. Dean A, Alamillos F, Garcia-López A, Sanches J, Penãlba M. The bucal fat pad flap in oral recontruction. Head Neck 2001 ;23:383-8.

11. Martín-Granizo R, Naval L, Costas A, Goizueta C, Rodriguez F, Monje F, Muñoz M, Diaz F. Use of buccal fat pad to repair intraoral defects: review of 30 cases. Br J Oral Maxillofac Surg 1997;35:81-4.

12. Egyedi P. Utilization of the buccal fat pad for closure of oroantral and/ or oro-nasal communication. J Maxillofac Surg 1977;5:241-4.

13. Hai HK. Repair of palatal defects with unlined buccal fat pad grafts. Oral Surg Oral Med Oral Pathol 1988;65:523-5.

14. Schow SR. Doença odontogênica do seio maxilar. In: Peterson LJ, Ghali GE, Larsen P, Waite PD. Cirurgia Oral e MaxiloFacial Contemporânea. $2^{a}$ ed. Rio de Janeiro: Guanabara Koogan; 1996.

15. Baumann A, Ewers R. Application of the buccal fat pad in oral reconstruction. J Oral Maxillofac Surg 2000;58:389-92. 